\title{
Safety of users in road evacuation: demand models
}

\author{
F. Russo \& G. Chilà \\ Department of Computer Science, Mathematics, \\ Electronics and Transportation, \\ Mediterranea University of Reggio Calabria, Italy
}

\begin{abstract}
The aim of this work is to propose a demand model for the simulation of a transportation system in emergency conditions. The model is specified, calibrated and validated using data obtained from real experimentation in the urban area of Melito Porto Salvo in the province of Reggio Calabria (Italy), in relation to the research project SICURO, organized by LAST - Laboratory for Transport Systems Analysis and funded by the Calabria Regional Authority (EU Structural Funds 2000-2006). In this paper we analyse a formal demand model subdivided into the following sub-models: generation; modal split with distribution. All sub-models were validated using formal and informal tests.

Keywords: emergency condition, simulation, demand model.
\end{abstract}

\section{Introduction}

A transportation demand model can be defined as a mathematical relationship associating the average values of demand flows with their main characteristics to given activities and transportation supply systems. The literature proposes several mathematical models to simulate travel demand, which are based on different assumptions and that can be subdivided in relation to different elements $[3,5]$ :

- type of choice implicitly or explicitly simulated by the model;

- approach taken for simulating travel demand, i.e. the reciprocal conditioning of decisions;

- basic assumptions of the models, which can be behavioural if they derive from explicit assumptions about user choice behaviour, or descriptive 
otherwise. Predominantly, the behavioural models used are members of the family of discrete choice models, which are defined in respect of the decision maker, finite choice set, attributes and parameters, and random residuals $[1,10]$.

Models of all types are also classified as either aggregate or disaggregate.

The use of demand models to simulate an evacuation involves various problems connected with most cases that may lead to a state of emergency. The events that can generate emergencies can be classified in relation to [6-8]:

- event kind, which can be natural or anthropogenic;

- effect in time, which can be immediate or delayed $\left(\mathrm{t}_{1}, \mathrm{t}_{3}\right)$; in particular, in the demand analysis, we consider a delayed or immediate approach, in relation to the time gap available between the time $t_{1}$ at which the dangerous event will happen is known and the time $t_{3}$ when the event starts its effects on the population; during this gap there is the possibility to evacuate the population and then reduce the effect when the event occurs, in the right extreme of the interval [9];

- effect in space, which can be punctiform or diffuse;

- effect in a transport system, which may be on demand, supply or demandsupply interaction.

When a dangerous event occurs, in emergency conditions, demand models specified and calibrated in ordinary conditions cannot be directly applied for several reasons:

- multiplicity of decision-makers; in this context it is necessary to consider at least two decision-makers: the citizen user, who has to decide in some cases whether to act; the public decision-maker, who may impose or advise some citizen user choices;

- definition of choice set, which may differ for emergency scenarios and for decision makers;

- statistical and probabilistic aspects: quantity of variance, presence or not of covariance, hypothesis about the random residual distribution;

- attributes, which may be relevant or not in comparison to the ordinary conditions;

- parameters, which may have different reciprocal substitution rates from those in ordinary conditions;

Moreover, in emergency conditions the analyst must consider possible targets set by the public decision-maker, in order to reduce system management costs, maximise the system utility (safety, security) and reduce traffic incidents [7].

Targets can be established in relation to:

- generation, regarding the citizen user's possibility to evacuate independently of the public decision-maker's targets or otherwise;

- departure time, regarding the citizen user's possibility to evacuate in a time independently of the public decision-maker's targets or otherwise;

- distribution, regarding the citizen user's possibility to go to the refuge area established by the public decision maker, or otherwise;

- modal split, regarding the citizen user's possibility to choose the transport mode or otherwise; 
- route choice, regarding the citizen user's possibility to choose the path or otherwise.

Of course, to simulate an evacuation we need to start from the knowledge of the category of people who will be in the zone at time $t_{1}$, who will be called people present, and, for each category, what decisions will be taken: to move or not; if so, where to and on what mode. First, as in ordinary conditions, the analyst has to define the study area and develop zoning and socio-economic analysis $[2,4]$.

In section 2 we propose a model to simulate evacuation demand in emergency conditions; in section 3 we describe the experiment, parameter calibration and application of the proposed model; in the last section we present the results obtained.

\section{Proposed demand model}

The proposed demand model is subdivided into the following sub-models:

- generation;

- modal split with distribution.

The generation model gives the level of demand in the study area according to the reference period and the population category. The modal split gives the number of people using a given transport mode from a certain origin to a certain refuge area, with alternatives including pedestrian transport, cars, buses and emergency vehicles for particular categories of people. For the distribution model, in emergency conditions and in the absence of targets, we note that the decision-maker chooses the refuge area and the transport mode at the same time or he/she chooses the transport mode first and then the destination. As regards the effect in time, for all sub-models we suppose a delayed approach.

\subsection{The generation model}

The generation model gives the mean number of people to evacuate in the study area in the reference period.

In this work we consider:

- the citizen user as the decision maker;

- a choice set including the alternatives present or otherwise in the reference period and, for people present, the alternatives willing or not to evacuate;

- attributes and parameters related to socio-economic property;

- statistical approach.

Moreover, we consider the absence of targets.

The model was developed for the following categories:

- residents within the area;

- non-residents who systematically reach the area for work (employees), and, in particular, school staff and pupils;

- non-residents who occasionally reach the area for shopping or other activities (occasional customers);

- weak users. 
Demand $d_{E, r}(h)$ of people present in the study area in the reference period $h$, per category, will be:

$$
d_{E, r}(h)=d_{E R, r}(h)+d_{E W, r}(h)+d_{E C, r}(h)+d_{E S, r}(h)+d_{E D, r}(h)
$$

where

$\mathrm{d}_{\mathrm{ER}, \mathrm{r}}(\mathrm{h})$ is the demand of people present in the resident category, specified as

$$
\mathrm{d}_{\mathrm{ER}, \mathrm{r}}(\mathrm{h})=\mathrm{f}_{\mathrm{ER}, \mathrm{r}}\left(\mathrm{R}_{\mathrm{r}}, \mathrm{FL}_{\mathrm{r}}, \mathrm{NS}_{\mathrm{r}}, \mathrm{NR}_{\mathrm{r}}, \mathrm{NC}_{\mathrm{r}}, \mathrm{E}_{\mathrm{j}, \mathrm{r}}, \mathrm{m}_{\mathrm{p}}(\mathrm{h}), \mathrm{m}_{\mathrm{ER}}(\mathrm{h}), \alpha_{\mathrm{i}}(\mathrm{h})\right)
$$

with

$\mathrm{R}_{\mathrm{r}} \quad$ resident number in zone $\mathrm{r}$;

$\mathrm{FL}_{\mathrm{r}} \quad$ percentage of actives on residents in zone $\mathrm{r}$;

$\mathrm{NS}_{\mathrm{r}}$ percentage of pupils over residents in zone $\mathrm{r}$;

$\mathrm{NR}_{\mathrm{r}}$ percentage of retired people over residents in zone r;

$\mathrm{NC}_{\mathrm{r}}$ percentage of housewives over residents in zone $\mathrm{r}$;

$\mathrm{NF}_{\mathrm{r}}$ family number in zone $\mathrm{r}$;

$E_{i} \quad$ percentage of residents with age in the range $j$;

$\mathrm{m}_{\mathrm{p}}(\mathrm{h})$ generation coefficient for purpose $\mathrm{p}$ in period $\mathrm{h}$;

$\alpha_{i} \quad$ calibrating parameters;

$\mathrm{m}_{\mathrm{ER}}(\mathrm{h})$ calibrating the attendance coefficient per resident category in period $\mathrm{h}$.

$\mathrm{d}_{\mathrm{EW}, \mathrm{r}}(\mathrm{h})$ is demand of people present in the employee category, specified as

$$
\mathrm{d}_{\mathrm{EW}, \mathrm{r}}(\mathrm{h})=f_{\mathrm{EW}, \mathrm{r}}\left(\lambda_{\mathrm{W}}(\mathrm{h}), \mathrm{NW}_{\mathrm{r}}\right)
$$

with

$\mathrm{NW}_{\mathrm{r}}$ employee number in zone $\mathrm{r}$;

$\lambda_{\mathrm{W}}(\mathrm{h})$ calibrating parameter.

$d_{E C, r}(h)$ is the demand of people present in the occasional customer category, specified as

$$
\mathrm{d}_{\mathrm{EC}, \mathrm{r}}(\mathrm{h})=f_{\mathrm{EC}, \mathrm{r}}\left(\lambda_{\mathrm{C}}(\mathrm{h}), \mathrm{NW}_{\mathrm{r}}\right)
$$

with

$\mathrm{NW}_{\mathrm{r}}$ employee number in zone r;

$\lambda_{\mathrm{C}}(\mathrm{h})$ calibrating parameter.

$d_{E S, r}(h)$ is the demand of people present in the school staff category, specified as

$$
\mathrm{d}_{\mathrm{ES}, \mathrm{r}}(\mathrm{h})=f_{\mathrm{ES}, \mathrm{r}}\left(\lambda_{\mathrm{S}}(\mathrm{h}), \mathrm{NS}_{\mathrm{r}}\right)
$$

with

$\mathrm{NS}_{\mathrm{r}}$ the teacher and pupil number in zone $\mathrm{r}$;

$\lambda_{\mathrm{S}}(\mathrm{h})$ calibrating parameter.

$d_{E D, r}(h)$ is the demand of people present in the weak user category, specified as

$$
\mathrm{d}_{\mathrm{ED}, \mathrm{r}}(\mathrm{h})=f_{\mathrm{ED}, \mathrm{r}}\left(\lambda_{\mathrm{ED}}(\mathrm{h}), \mathrm{ND}_{\mathrm{r}}\right)
$$

with

$\mathrm{ND}_{\mathrm{r}} \quad$ weak user number in zone $\mathrm{r}$;

$\lambda_{\mathrm{ED}}(\mathrm{h})$ calibrating parameter. 
Demand of people present willing to evacuate will be:

$$
\mathrm{d}_{\mathrm{E}_{\xi}, \mathrm{r}}(\mathrm{h})=\sum_{\mathrm{k}} \mathrm{d}_{\mathrm{Ek}_{\xi}, \mathrm{r}}(\mathrm{h})=\sum_{\mathrm{k}} \mathrm{d}_{\mathrm{Ek}, \mathrm{r}}(\mathrm{h}) \cdot \xi_{\mathrm{k}}
$$

with category index $\mathrm{k}$ and calibrating parameter $\xi_{\mathrm{k}}$.

\subsection{Modal split with distribution model}

The modal split gives the number of people using a given transport mode from a certain origin to a certain refuge area; the distribution model gives the probability of trips undertaken by people going to a certain refuge area, given departure from zone $\mathrm{r}$ and period $\mathrm{h}$.

In this work we assume modal split and distribution are targeted for school staff and weak user categories. For the remaining categories we propose:

- a modal split model;

- a distribution model;

- a modal split with distribution model.

We propose several specifications: some of them are related to the whole population, others to particular employee groups. For the modal split model we assume the absence of targets and:

- the citizen user as the decision-maker;

- a choice set including car and pedestrian alternatives;

- attributes and parameters related to level of service, socio-economic properties and alternative specific attributes (ASA);

- a behavioural approach, with random residual $\varepsilon_{\mathrm{j}}$ independently and identically distributed according to a Gumbel random variable of zero mean and parameter $\theta$.

The systematic utility for the alternatives will be specified as:

$$
\begin{gathered}
\mathrm{V}_{\text {Pedestrian }}=f_{\text {Pedestrian }}\left(\mathrm{T}_{\mathrm{RP}}, \mathrm{D}, \text { Pedestrian, } \mathrm{E}_{\mathrm{i}}, \text { Women }\right) \\
\mathrm{V}_{\mathrm{Car}} \quad=f_{\text {Car }}\left(\mathrm{T}_{\mathrm{RC}}, \mathrm{D}, \text { Car, L, CWork }\right)
\end{gathered}
$$

with
$\mathrm{T}_{\mathrm{RP}} \quad$ time on pedestrian network [10];
$\mathrm{T}_{\mathrm{RC}} \quad$ time on road network [10];
Pedestrian ASA for pedestrian alternative;
Car ASA for car alternative;
$\mathrm{D}$ distance as the crow flies between origin and refuge area;
$\mathrm{E}_{\mathrm{i}} \quad$ dummy equal to 1 for citizen users of age in range $\mathrm{i}$;
Women dummy equal to 1 for women, 0 otherwise;
L economic dummy (professional level);
CWork dummy equal to 1 if the worker used a car to go to work, 0 otherwise.

For the distribution model we assume a refuge area established by the public decision-maker and:

- the citizen user as the decision-maker;

- a choice set which includes the alternatives of refuge area fixed by public decision maker (RAF) or other refuge area (RAO); 
- attributes and parameters related to level of service, socio-economic properties and alternative specific attributes (ASA);

- a behavioural approach, with random residual $\varepsilon_{\mathrm{j}}$ independently and identically distributed according to a Gumbel random variable of zero mean and parameter $\theta$.

The systematic utility for the alternatives will be specified as:

$$
\begin{gathered}
\mathrm{V}_{\mathrm{RAF}}=f_{\mathrm{RAF}}\left(\mathrm{Z}_{\mathrm{r}}, \mathrm{D}\right) \\
\mathrm{V}_{\mathrm{RAO}}=f_{\mathrm{RAO}}(\mathrm{L}, \text { Women })
\end{gathered}
$$

with

$\mathrm{Z}_{\mathrm{r}} \quad$ dummy origin zone;

D distance as the crow flies between origin and refuge area;

Women dummy equal to 1 for women, 0 otherwise;

L economic dummy (professional level).

Importantly, the proposed distribution model is not designed to simulate citizen user choice as a usual distribution model. According to a behavioural approach, the usual distribution model simulates destination choice. Generally, the destination zone is a homogeneous area including several elementary destinations, which are represented as discrete points. In order to obtain the destination choice probability, a size variable is included in the systematic utility of each zone. The size variable considers the effects of elementary destinations [5].

In this work, the proposed distribution model is related to the possibility that the citizen user may or may not follow the decision maker's advice. Alternatives are not homogeneous areas, but discrete points fixed by a decision-maker. In this case the level of service attributes are not significant to simulate citizen user behaviour; only socio-economic variables are used.

For modal split with a distribution model we assume the absence of constraints and:

- the citizen user as the decision-maker;

- a choice set which includes the alternatives of pedestrian with refuge area (Pedestrian,RA) or car with refuge area (Car,RA);

- attributes and parameters related to level of service;

- a behavioural approach, with random residual $\varepsilon_{\mathrm{j}}$ independently and identically distributed according to a Gumbel random variable of zero mean and parameter $\theta$.

The systematic utility for the alternatives will be specified as:

$$
\begin{aligned}
\mathrm{V}_{\text {Pedestrian,RA }} & =f_{\text {Pedestrian,RA }}\left(\mathrm{T}_{\mathrm{RP}, \mathrm{RA}}, \mathrm{D}_{\mathrm{RP}, \mathrm{RA}}\right) \\
\mathrm{V}_{\mathrm{Car}, \mathrm{RA}} & =f_{\mathrm{Car}, \mathrm{RA}}\left(\mathrm{T}_{\mathrm{RC}, \mathrm{RA}}, \mathrm{D}_{\mathrm{RC}, \mathrm{RA}}\right)
\end{aligned}
$$

with
$\mathrm{T}_{\mathrm{RP}, \mathrm{RA}}$
time on pedestrian network [10];
$\mathrm{T}_{\mathrm{RC}, \mathrm{RA}}$
$\mathrm{D}_{\mathrm{RP}, \mathrm{RA}}$
time on road network [10];
$\mathrm{D}_{\mathrm{RC}, \mathrm{RA}}$
distance on pedestrian network [10];
distance on road network [10]. 


\section{Experimentation and application}

The proposed model was calibrated using data obtained from a real experiment in the urban area of Melito Porto Salvo in the province of Reggio Calabria (Italy), in relation to the SICURO research project, organized by the LAST Laboratory for Transport Systems Analysis and funded by the Calabria Regional Authority (EU Structural Funds 2000-2006).

In order to calibrate the model we performed:

- a survey to ascertain the socio-economic attributes of the study area;

- a pre-trial, where only part of the public offices and school were evacuated,

- a trial, where the whole area was evacuated.

The survey collected data related to buildings and people present in the study area, subdivided into the following categories:

- for the buildings: residence; public activity; private activity; school;

- for the population: resident; employee; occasional customer; staff and pupil; weak user.

The study area is $42990 \mathrm{~m}^{2}$ and was subdivided into 11 traffic zones, which include 23 residential buildings, 1 school, 1 town hall, 1 court, 3 public facilities and 28 mixed buildings.

For users of each zone we conducted:

- an RP (revealed preferences) survey, to ascertain socio-economic properties;

- a SP (stated preferences) survey, to estimate the number of people usually present and their willingness to evacuate.

In table 1 we propose the main characteristics of the study area regarding population categories.

The data were recorded and developed by laboratory analysis. During the experiment, information was collected with manual/automatic tools, 30 video cameras and by interviewing evacuees. From such surveys we can obtain variables for calibrating models.

The generation model was calibrated using the least square method; modal split and distribution were calibrated using the maximum likelihood method. For the observed data, the least squares of model unknowns are the values minimizing the sum of square deviations, comparing the data to model predictions. In Maximum Likelihood estimation the values of the unknown parameters are obtained by maximizing the probability of observing the choices made by a sample of users.

In table 2 we list all calibrated parameters, which were used in two model classes:

- general model related to the whole population;

- model related to employee groups.

Table 1: $\quad$ User category in the study area.

\begin{tabular}{lc}
\hline User category & Number \\
\hline Resident & 255 \\
Employee & 212 \\
Occasional customer & 170 \\
Staff and pupil & 159 \\
Weak user & 5 \\
\hline
\end{tabular}


Table 2: $\quad$ Calibrated parameter.

\begin{tabular}{|c|c|c|c|c|c|c|c|}
\hline & Calibrated parameter & Gene & ition & Moc & lal split & $\begin{array}{c}\text { Distributio } \\
\mathrm{n}\end{array}$ & $\begin{array}{l}\text { Modal split } \\
\text { with } \\
\text { distribution }\end{array}$ \\
\hline & & $\begin{array}{c}\text { Residen } \\
\mathrm{t}\end{array}$ & $\begin{array}{c}\text { Non- } \\
\text { reside } \\
\text { nt }\end{array}$ & $\begin{array}{c}\text { Genera } \\
1\end{array}$ & $\begin{array}{l}\text { Employee } \\
\text { group }\end{array}$ & $\begin{array}{l}\text { Employee } \\
\text { group }\end{array}$ & $\begin{array}{l}\text { Employee } \\
\text { group }\end{array}$ \\
\hline & $\begin{array}{lll}\begin{array}{l}\text { Active's } \\
\text { residents }\end{array} & \text { percentage } & \text { over }\end{array}$ & $\mathrm{X}$ & & & & & \\
\hline & $\begin{array}{l}\text { Pupil percentage over } \\
\text { residents }\end{array}$ & $\mathrm{X}$ & & & & & \\
\hline & $\begin{array}{l}\text { Housewife percentage over } \\
\text { residents }\end{array}$ & $\mathrm{X}$ & & & & & \\
\hline & $\begin{array}{l}\text { Retired percentage over } \\
\text { residents }\end{array}$ & $\mathrm{X}$ & & & & & \\
\hline & $\begin{array}{l}\begin{array}{l}\text { Percentage of } \\
\text { younger than } 14\end{array} \text { and oldents } \\
\text { than } 5 \text { years }\end{array}$ & $\mathrm{X}$ & & & & & \\
\hline & $\begin{array}{l}\text { Percentage of residents } \\
\text { younger than } 19 \text { and older } \\
\text { than } 15 \text { years }\end{array}$ & $\mathrm{X}$ & & & & & \\
\hline & $\begin{array}{l}\begin{array}{l}\text { Percentage of residents } \\
\text { younger than } 24 \text { and older } \\
\text { than } 20 \text { years }\end{array}\end{array}$ & $\mathrm{X}$ & & & & & \\
\hline & $\begin{array}{l}\text { Percentage of residents } \\
\text { younger than } 65 \text { and older } \\
\text { than } 25 \text { years }\end{array}$ & $\mathrm{x}$ & & & & & \\
\hline & $\begin{array}{l}\text { Percentage of residents over } \\
65 \text { year }\end{array}$ & $\mathrm{X}$ & & & & & \\
\hline & Family number & $\mathrm{X}$ & & & & & \\
\hline & Employee number & & $\mathrm{X}$ & & & & \\
\hline & Staff and pupil number & & $\mathrm{X}$ & & & & \\
\hline & Weak user number & & $\mathrm{X}$ & & & & \\
\hline$\sum_{0}^{n}$ & $\begin{array}{l}\text { Dummy for employees of age } \\
\text { below } 45 \text { years }\end{array}$ & & & & $\mathrm{X}$ & & \\
\hline 它 & $\begin{array}{l}\text { Dummy if the employee level } \\
\text { is higher than } 2,0 \text { otherwise }\end{array}$ & & & & $\mathrm{X}$ & $\mathrm{X}$ & \\
\hline $\mathfrak{1}_{0}^{1}$ & $\begin{array}{l}\text { Dummy if the employee level } \\
\text { is higher than } 3,0 \text { otherwise }\end{array}$ & & & & $\mathrm{X}$ & & \\
\hline O & $\begin{array}{l}\text { Dummy equal to } 1 \text { if the user } \\
\text { is a woman, } 0 \text { otherwise }\end{array}$ & & & & $\mathrm{X}$ & $\mathrm{X}$ & \\
\hline & $\begin{array}{l}\text { Time on the pedestrian } \\
\text { network from origin to the } \\
\text { refuge area }\end{array}$ & & & $\mathrm{X}$ & & & $\mathrm{X}$ \\
\hline$\stackrel{5}{3}$ & $\begin{array}{l}\text { Time on the road network } \\
\text { from origin to the refuge area }\end{array}$ & & & $\mathrm{X}$ & & & $\mathrm{X}$ \\
\hline$\frac{1}{y}$ & $\begin{array}{l}\text { Distance as the crow flies } \\
\text { between origin and refuge area }\end{array}$ & & & $\mathrm{X}$ & $\mathrm{X}$ & & \\
\hline 盆 & $\begin{array}{l}\text { Distance on the pedestrian } \\
\text { network between origin and } \\
\text { refuge area }\end{array}$ & & & $\mathrm{X}$ & & & \\
\hline & Dummy origin for zone 10 & & & & & $\mathrm{X}$ & \\
\hline
\end{tabular}

The first class includes a larger and more heterogeneous sample of people than the second, for which, however, more information and socio-economic characteristics are available. Therefore formal tests are more suitable for the second than for the first class. On the other hand, the first class model value is applicable to all user categories and is thus very often usable. Informal tests are suitable for all calibrated models.

The proposed model was validated by verifying the reasonableness and the significance of estimated coefficients, as well as the model's ability to reproduce 
the choices made by a sample of users. All these activities can be completed with appropriate tests of hypotheses for a sample of users.

In this work, we performed informal and formal tests. Informal tests are based on the expectations on the signs of the coefficient calibrated. Formal tests allow us to verify different assumptions on Maximum Likelihood estimates using asymptotic results. The t-student statistic shows that all the estimates of the coefficient are significantly different from zero. With rho-square we can verify the model's goodness of fit, that is its ability to reproduce the choices made by a sample of users.

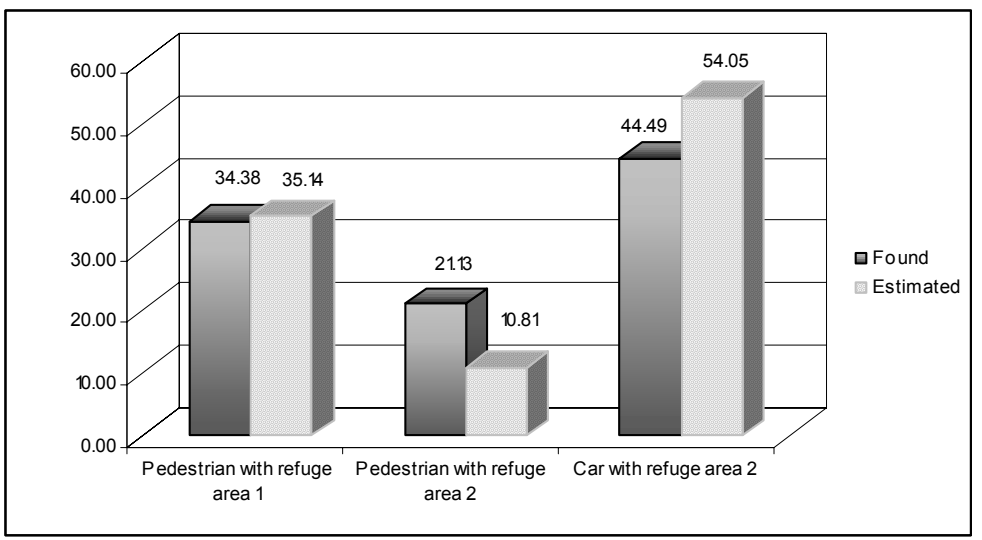

Figure 1: $\quad$ Modal split with distribution probability.

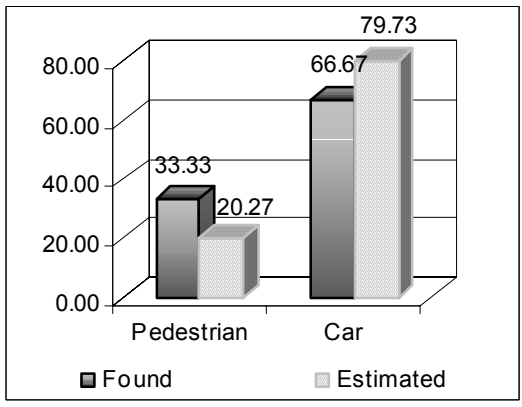

Figure 2: $\quad$ Modal split probability.

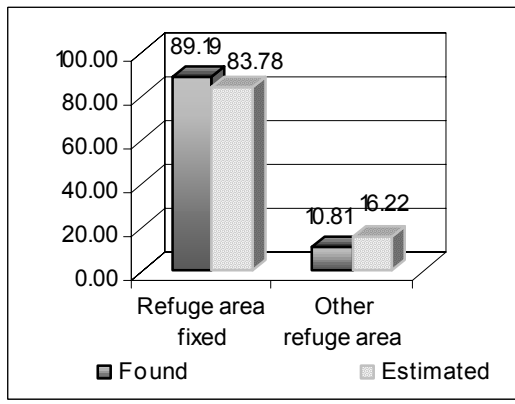

Figure 3: Distribution probability.

Finally, we propose a comparison between observed and estimated data related to modal split, distribution and modal split with distribution choice, fig. $1-3$. In relation to the modal split model our results showed that, for the categories of residents, employees and occasional customers, a percentage of $80 \%$ chose to go to the refuge area by car, the remaining percentage on foot. For school staff and weak user categories we hypothesised a deterministic choice of school bus and emergency vehicles respectively. As regards the distribution model, according to our results only $90 \%$ of the total are willing to follow the 
public decision-maker's advice. The comparison between estimated and observed choice percentages is favourable.

\section{Conclusion}

Analysis and modelling of transportation systems in emergency conditions requires further studies. In such conditions it is necessary to rearrange standard procedures such as specification and calibration of demand models for the different choice levels for citizen users and for the public decision-maker.

In this paper a general model to simulate transport demand in emergency conditions is explained. We classified people into several categories and, for each category, we proposed a generation model and a modal split with distribution model. The structure of the proposed model is satisfactory for all population categories. Database improvements in the future will allow better results to be obtained about formal test related to calibrated parameters.

\section{References}

[1] M. Ben Akiva, S. Lerman, Discrete choice analysis: theory and application to travel demand (MIT Press, Cambridge, MA, 1985).

[2] G. E. Cantarella, E. Cepollina, G. Delfino, M. Di Gangi, A. Pratelli, C. Rindone, F. Russo and A. Vitetta Linee guida per la redazione dei piani di evacuazione mediante la simulazione dei sistemi di trasporto in condizioni di emergenza. (Laruffa editore, Reggio Calabria, 2005)

[3] E. Cascetta, Transportation systems engineering: theory and methods (Kluwer Academic Press, 2001).

[4] M. Di Gangi (ed.) Modelli e metodi per l'analisi delle reti di trasporto in condizioni di emergenza: contributi metodologici ed applicativi (EditricErmes, Potenza, 2005).

[5] T.A. Domencich, D. McFadden Urban travel demand: a behavioural analysis (American Elsevier, New York, 1975).

[6] F. Russo, A. Vitetta, The road network design problem to improve the safety during exogenous flow perturbations, Proceedings of the $29^{\text {th }}$ ISATA Conference (Florence, 1996).

[7] F. Russo (ed.), Evacuazione dei sistemi urbani. Metodi quantitativi per l'analisi di un sistema di trasporto in condizioni di emergenza. (Franco Angeli, Milan, 2004).

[8] F. Russo, A. Vitetta, Risk in anthropic environments: methodologies for risk evaluation and exposition reduction in Environmental Health Risk III, Brebbia et al. (WIT Press, Boston, 2005).

[9] F. Russo, A. Vitetta, Safety of users in road evacuation: general methodology and main results (in the same proceedings).

[10] K. Train, Discrete choice methods with simulation (MIT Press Cambridge, Massachusetts, 2003).

[11] A. Vitetta, G. Musolino, A. Marcianò, Safety of users in road evacuation: supply and supply-demand interaction models for users (in the same proceedings). 